\title{
中性子放射化分析法によるイン石中のヒ紊およびアンチモンの定且
}

\author{
（凅和 35 年 10 月 18 日受理）
}

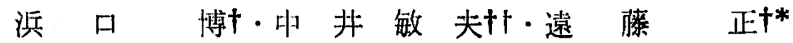

イン石中のヒ聚，アンチモンの含有量についての報告は少なく，また值には大きな差がある。そてで微量分析に有力な方法であ る中性子放射化分析法を適用することを考えた。

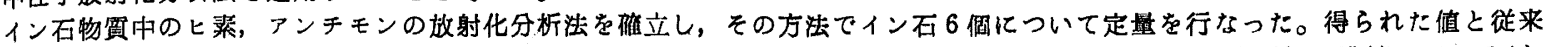

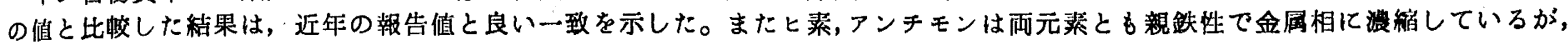
・素の方がさらに親斜性が強いととが示された。

\section{1 緒雼}

最近の地球化学・宇宙化学の目ざましい発展にともない元絜の 宇宙存在比 (cosmic abundance) について1)838), またこれを説 明する元婪(核種)の創成理論についてい)5)，いろいろの論境が提 出されている。元絜の宇宙存在比の推定には, イン石の分析値が 大きな役割を演じている。しかるにイン石中のヒ秦やアンチモン の偡については，いままでのところわずかの報告しかなく，しか るそれらの值の間には大きな差異がある677。その原因として考 えられるものには, イン石中のヒ素, アンチモンが微量であるこ と，また従来の值は適用された分析法の感度ぎりぎりのところで 得られたものが多い点，およびこのような微量分析にしばしばと るなう分析試薬からの污染などがある。よってイン石中のヒ素, アンチモン含量について再検討が 要望されている 現状にかんが み，著者らは極微量の分析に対して有力な手段である放射化分析 法を適用し，イン石中の两元素の定量を行なわんとした。

七素およびアンチモンの放射化分析法については，すでにいく つかの竍告がある8が，鉄合金やヶイ酸塩岩石に対する分析法は まだ報告されていない。そこで鉄合金およびケイ酸塩岩石に対す る七素およびアンチモンの放射化分析法を確立し，その方法をイ ン石に適朋して二，三の絬果を得たのでこれを報告する。

\section{2 実験}

\section{1 眐料の調赠}

イン鉄は $0.6 〜 1.2 \mathrm{~g}$ のブロックに切りとり，希塩酸で表面の 污染を除き, ついで㿟留水, アルコール, エーテルで洗浄, 乾嬠, 精科して石英管に封入した。

イン石（ケイ陵塩）は，粉未化された試料 $0.5 \mathrm{~g}$ 精科して石 英管に封入した。パラサイトは，确いてガラス質のケイ酸塩相と

東京教府大学理学部化学数空, 東京都交京区

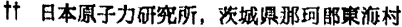

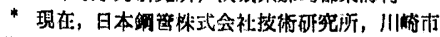

1) V. M. Goldschmidt, Skrifter Norske Videnskaps-Akad. Oslo 1 Mat-Naturw. Klasse 4, 120 (1937).

2) H. Brown, Rev. Mod. Phys. 21, 628 (1949).

3) H. E. Suess, H. C. Urey, ibid. 28, 53 (1956).

4) R. A. Alpher, R. C. Herman, ibid. 22, 153 (1950).

5) G. Gamow, "The Creation of the Universe"

6) K. Rankama, Th. G. Sahama, "Geochemistry"

7) H. Onishi, E. B. Sandell, Geochim. ef Cosmochim. Acta 7, 1 (1955); 8, 213 (1955).

8) たとえば, J. E. Hudgens, Jr., et al., Anal. Chem. 24, 171 (1952); A. A. Smales, et al., ibid. 24, 717 (1952) J. A. James, et al., Z. anal. Chem. 155, 464 (1957) など.
金属相とを磁石をむちいて分離した。ケイ酸塩相はさらに $6 \mathrm{~N}$ 塩 酸で付着している金属相を除き，蒸留水，アルコール，エーテル で洗浄，乾燥して試料とした。金風相は，肉眼でケイ酸塩相を含 まない比較的大きな塊を洗浄处理して試料とした。

標準 (比較試料) には，中性子放射化分析に必要な注意 ${ }^{\ominus}$ のも とに, 試料の組成とほぼ似た組成の偽イン鉄および媯イン石溶液 を試薬を混合して調製した。この溶液の一定量（イン鉄は $0.2 \mathrm{~g}$ 相当，イン石は $0.5 \mathrm{~g}$ 相当）を石英管にとり，これに装および アンチモンの標準溶液一定量を加えて赤外線ランプで乾嬠, 固化 させてから熔封した。

ポリエチレン製カプセルに試料と標準とをならべて入れ，これ を照射試料とした。

\section{2 中性子照射}

放射化の中性子源には, 日本原子力研究所の JRR-1 をるちい た。照射時間は 1 日最大 5 時間， $2 \sim 3$ 日間の咪続照射を行なっ

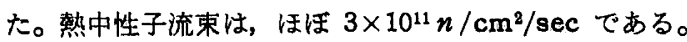

\section{3 化学操作}

目的放射能を他の放射能から放射化学的に純粋に分離する方法 を检討10)し，表1のようなう法を確立した。

表 1 イン石からヒ素, アンチモンの放射化学的分離法

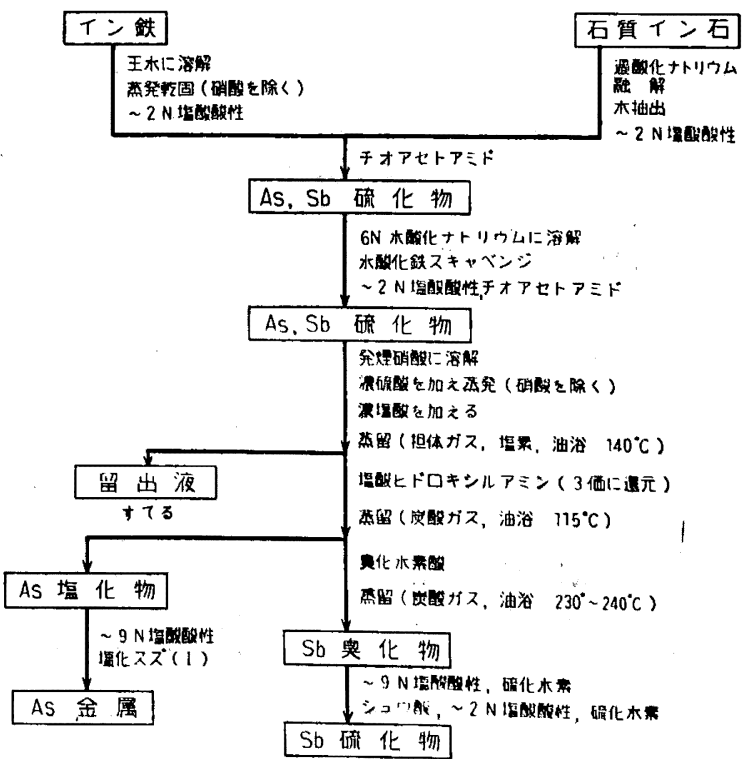

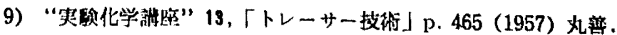

10) C. D. Coryell, N. Sugarman, "Radio chemical Studies: The Fission Products" 
まず定性分析第 2 属の常法にしたがい，酸性溶液からヒ素およ びアンチモンを硫化物として主放射能から分離し，ついでヒ素と アンチモンをハロゲン化物蒸留の方法により分嶉精製した。この 過程では，収率をあげるよりも他放射能より放射化学的に純な七 素およびアンチモンを得ることに留意した。

2.3.1 イン鉄の化学操作：試料を石英管よりとりだし，七素と アンチモンの担体（おのおの $13 \mathrm{mg}$ ）を入れたケルダールフラス コ中で王水に溶解する。完全に溶解したのちビーカーに移し, 蒸 発乾固して硝酸を除く。つぎに，ほほ $2 \mathrm{~N}$ 塩酸酸性溶液とし，チ オアセトアミドを加えて，ヒ素およびアンチモンを硫化物沈殿と し遠心分離する。チオアセトアミドによると硫化水素ガスを通ず ることにより生ずる気泡飛沫による污染のおそれがない。

硫化物を $6 \mathrm{~N}$ 水酸化ナトリウムに溶解，不溶物をのぞき，これ に塩化鉄(III) を加えて水酸化鉄スキャベンジを行なう。ここで水 酸化ナトリウム溶解のさいに付随したアルカリ不溶性の他放射能 はほとんど完全にのぞかれる。ふたたび溶液を塩酸酸性とし，チ オアセトアミドを加えてヒ素およびアンチモンを硫化物とし遠心 分離する。沈殿を発煙硝酸に溶解, 濃硫酸を加えて熱板上で加熱 し，硝酸を完全にのぞく。

つぎに Smales らの蒸留法11を応用して精製する。溶液を蒸 留器に移し，濃塩酸，スズ，ゲルマニウムの担体を加え，塩素が

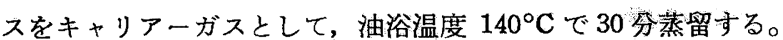
このときはスズとゲルマニウムのみが留出する。受器をとりか え, 濃塩酸と塩酸ヒドロキシルアミンを加え，七素およびアンチ モンを 3 価に還元，炭酸ガスをキャリアーガスとして油浴温度 $115^{\circ} \mathrm{C}$ で 90 分蒸留する。この留出液には素のみがくる。受器 をとりかえ，40\%臭化水素酸を加光，炭酸ガスをキャリアーガス として油浴温度 $230^{\circ} \sim 240^{\circ} \mathrm{C}$ で 30 分蒸留する。ここにアンチ モンが留出してくる。

七素の留出液は, 濃塩酸でほぼ $9 \mathrm{~N}$ の塭酸濃度とし, 塩化スズ （I）でヒ素を還元する。生成した黑色粉末状ヒ素を口過洗浄し， 乾燥, 秤量して化学収率を求め,アルミニウム板にマウントする。 アンチモンの留出液は，濃塭酸でほぼ 9N の酸濃度とし，七素 とテルルの担体を加えて硫化水素を飽和させる。ヒ素, テルルの 硫化物を口別し，口液にシュウ酸を加えてから $6 \mathrm{~N}$ 水酸化ナトリ ウムでほぼ 2N 酸性に中和し，ふたたび硫化水素を飽和させる。 统化アンチモンの沈殿を口過洗浄し，以下七素と同様に処理して 測定用試料をつくる。

2.3.2 イン石の化学操作: ニッケルルツボにヒ素およびアンチ モンの担体を入れ蒸発乾固しておく。照射した粉末試料（ケイ酸 塩）をルツボに入れ，過酸化ナトリウムを加えて融解する。融解 生成物は水で溶解し, 不溶物は王水で完全に溶解寸る。蒸発乾固 乙て硝酸をのぞき，塩酸でほほ $2 \mathrm{~N}$ 塩酸酸性とし，チオアセトア ミドを加えて硫化物沈殿をつくる。以下イン鉄と同様の操作によ り精製する。

2.3.3 標準試料の化学操作: 標準試料は石英管をくだき, ヒ絜, アンチモンの担体を加えたビーカー中で， $6 \mathrm{~N}$ 塩酸で内容物を完 全に 溶かしだす。溶液をほぼ $2 \mathrm{~N}$ 酸性として硫化物沈殿をつく り, 以下同様の操作を行なった。

\section{4 計 測}

放射能強度は端䓡型 $\mathrm{GM}$ 計数管（マイカ空の厚み $1.9 \mathrm{mg} / \mathrm{cm}^{2}$ ）

11) A. A. Smales, B. D. Pate, Anal. Chem. 24, 717 (1952).
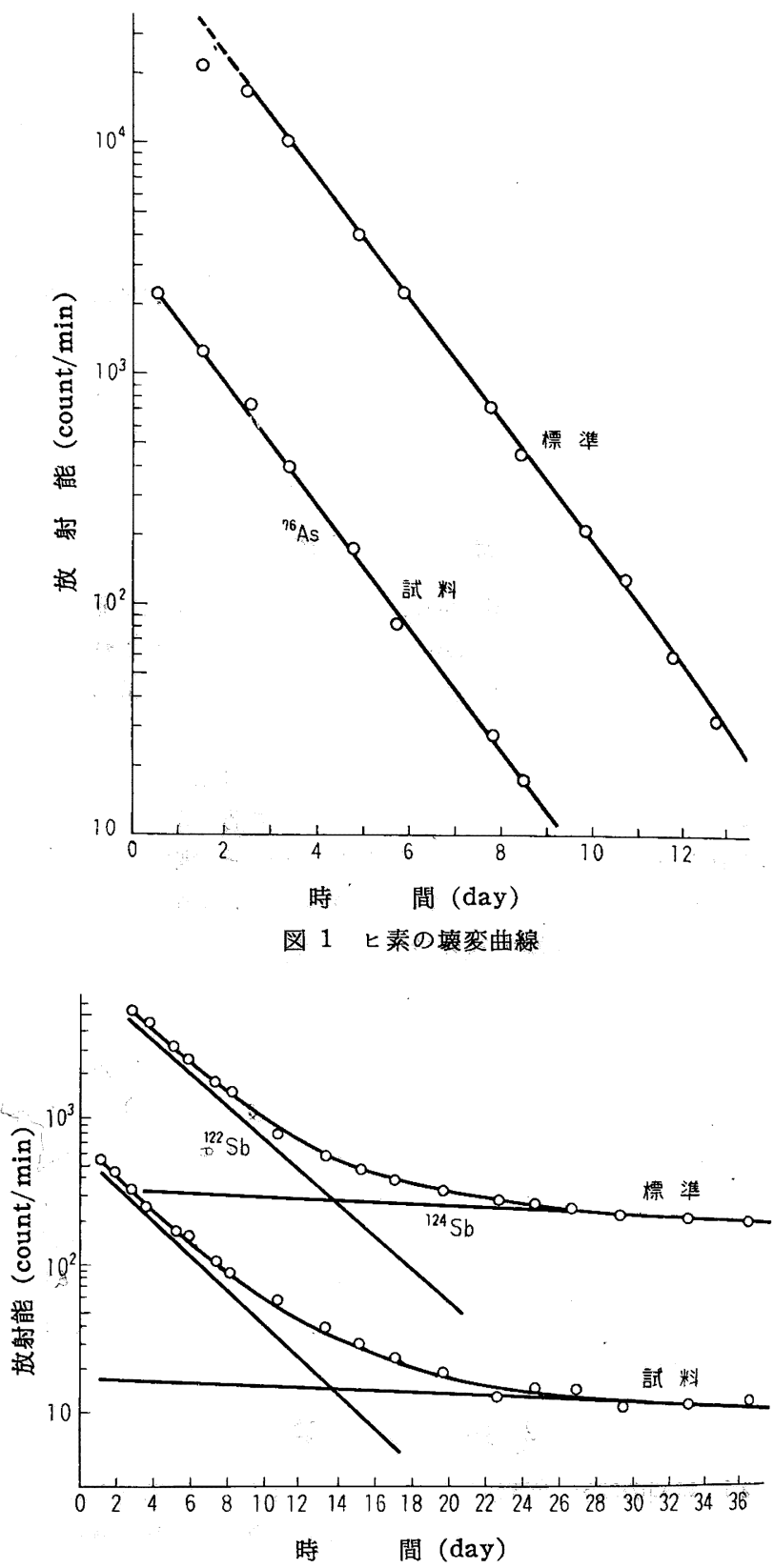

図 2 アンチモンの壊変曲線

をむちいて測定した。ヒ素の測定にはアルミニウム吸収板 $(266$ $\mathrm{mg} / \mathrm{cm}^{2}$ )をむちてて ${ }^{7} \mathrm{As}$ の影響を除いた。測定結果の1例を 図 1，2 k示す。

この半減期と，アルミニウム吸収板による $\beta$ 線のエネルギー測 定值文献值 $\left.{ }^{2}\right)$ とくく致し, 測定試料の放射化学的に純なるこ とを確認した。

\section{5 妨害元素}

核反応によって,目的とすると素やアンチモン以外の核種から， ヒ素やアンチモンの核種を生ずる可能性がある。これらの妨害に ついては十分検討しなければならない。

2.5.1 七素に対する妨害: 原子炉内の核反応により七素の放射

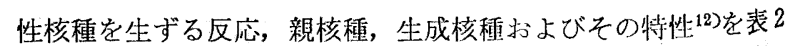

12) G. Friedlander, J. W. Kennedy, "Nuclear and Radio Chemistry" p. 421, 427 (1955) John Wiley \& Sons, Inc. New York. 
表 2 各種の核反応により生成すると素

\begin{tabular}{|c|c|c|c|c|c|c|c|}
\hline$(n, r)$ & $(n, \alpha)$ & $(n, p)$ & $(n, 2 n)$ & $(\gamma, p)$ & 生成核璉 & 半減期 & 壊変型式とエネルギー(MeV) \\
\hline & & ${ }^{74} \mathrm{Se}$ & ${ }^{75} \mathrm{As}$ & & ${ }^{74} \mathrm{As}$ & $17.5 \mathrm{~d}$ & $\begin{cases}\beta^{-}, & 1.36 \\
\beta^{+}, & 1.45\end{cases}$ \\
\hline${ }^{74} \mathrm{Ge}$ & & & & ${ }^{76} \mathrm{Se}$ & ${ }^{75} \mathrm{As}$ & 安 定 & \\
\hline${ }^{75} \mathrm{As}$ & ${ }^{79} \mathrm{Br}$ & ${ }^{76} \mathrm{Se}$ & & ${ }^{77} \mathrm{Se}$ & ${ }^{76} \mathrm{As}$ & $26.5 \mathrm{hr}$ & 2.98 \\
\hline${ }^{76} \mathrm{Ge}$ & & ${ }^{77} \mathrm{Se}$ & & & ${ }^{77} \mathrm{As}$ & $39 \mathrm{hr}$ & $\beta^{-}, \quad 0.70$ \\
\hline & ${ }^{81} \mathrm{Br}$ & ${ }^{78} \mathrm{Se}$ & & & ${ }^{78} \mathrm{As}$ & $90 \mathrm{~min}$ & $\beta^{-}, \quad 4.1$ \\
\hline
\end{tabular}

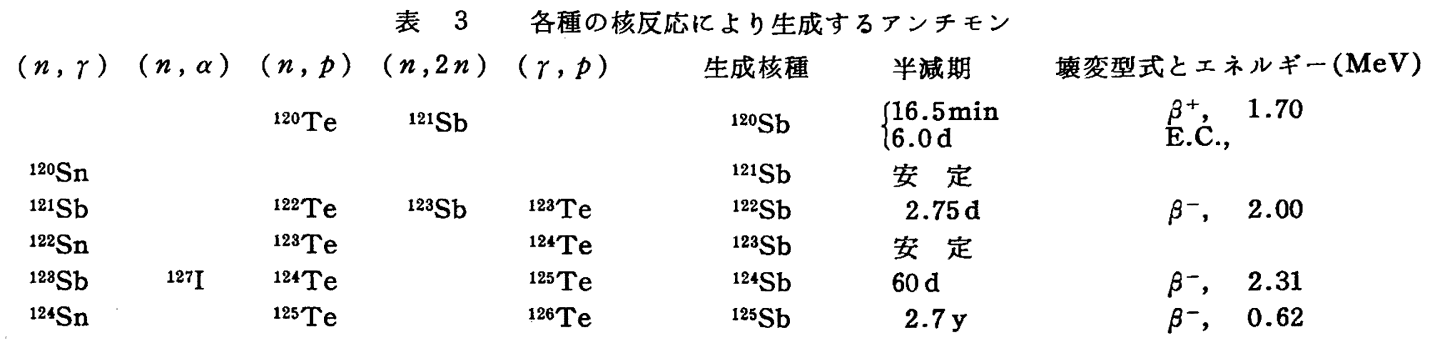

に示す。

生成する ${ }^{74} \mathrm{As} \sim{ }^{78} \mathrm{As}$ の放射能は，半减期が分単位，時間単位， 日単位の 3 群にわかれ，これらの間は壊変曲線の解析で区別する ととができる。 ${ }^{76} \mathrm{As}$ と ${ }^{77} \mathrm{As}$ は, 半減期の差だけからでは区別で きないが，目的核種の ${ }^{76} \mathrm{As}$ の $\beta^{-}$エネルギーは相当に大きく, かつ ${ }^{77} \mathrm{As}$ のそれと差があるから，アルミニウム吸収板で ${ }^{77} \mathrm{As}$ のそれをカットし ${ }^{76} \mathrm{As}$ だけを求めることができる。しかしこの ときは， ${ }^{76} \mathrm{As}$ の放射能強度も吸収板をむちいないときの約 $40 \%$ に減じた。

${ }^{74} \mathrm{Ge}(n, \gamma){ }^{75} \mathrm{Ge}$ の ${ }^{75} \mathrm{Ge}$ は 82 分の半減期で ${ }^{75} \mathrm{As}$ に壊変し， この ${ }^{75} \mathrm{As}$ が中性子照射中にふたたび $(n, r)$ 反応をして ${ }^{76} \mathrm{As}$ になる可能性があるが，ゲルマニウムに中性子照射をして生ずる ${ }^{6} \mathrm{As}$ の量はきわめて 少なく18), ゲルマニウムを主成分とする場 合以外は，七素の定量にその影響を無視してよい。 $(n, p),(n$, $\alpha),(\gamma, p)$ 反応はその核反応断面積も小さく14), またこの反応 を生ずる粒子エネルギーには一定の制限があるので, 微量成分で ある限りはその影響を無視してよい。

2.5.2 アンチモンに対する妨害: アンチモンの放射性核種を生 ずる反応, 親核種, 生成核種およびその特性 ${ }^{12)}$ を主要なもののみ 表 3 に示す。

アンチモンに対する妨害についても，七素に対する論議とまっ たく同様であり，スズ，テルル，ヨウ素が主成分である試料以外 は，その影響を無視してよい。

以上の論議から，イン石を対象とする場合ヒ素亡アンチモンの 定量において妨害となるものは ${ }^{76} \mathrm{Ge}$ のみとなり，この影響も吸 收板をもちいることでのぞくことができる。

\section{6 自己しゃへい}

試料が少量のさいには自己しゃへいの影響はない。著者らの別 のグループは, 金を測定元素として標準用につくった偽イン鉄を もちいて自己しゃへい勃果の検討を行なったが， $1.6 \mathrm{~g}$ まではそ

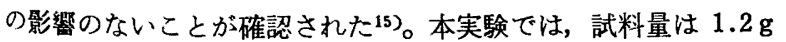
以下であるから自己しゃへいの影響はない。

13) A. A. Smales, Ann. Repts. Chem. Soc. 46, 285 (1949).

14) B. R. Curtis, J. M. Cork, Phys. Rev. 53, 681 (1938)! R. Sagane, et al., Proc. Phys. Math. Soc. Japan 21, 660 (1939); B. L. Cohen, Phys. Rev. 81, 184 (1951).

15）沃口，中井，角本，第 2 回故射化学討論会(於京都)諈演，日化82，1489(1961).

\section{7 自己吸収}

測定に関する問題はいろいろあるが，同一のカウンターをもち いつねに同一条件で測定すれば，自己吸収以外の影響は除くこと ができる。

ヒ素とアンチモンの自己吸収効果を検討した結果を図 $3 ， 4$ に 示す。自己吸収の影響がなければ，試料厚みの増大にともなって

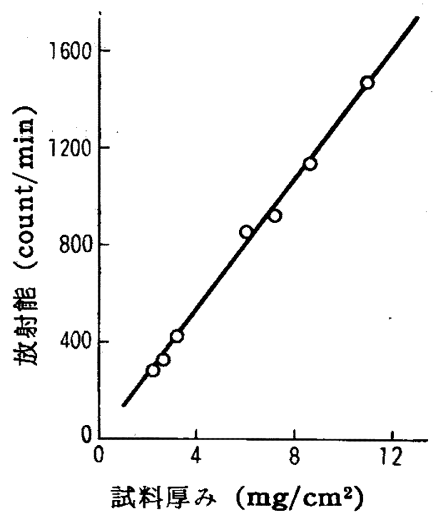

図 3 As の自己吸収曲線

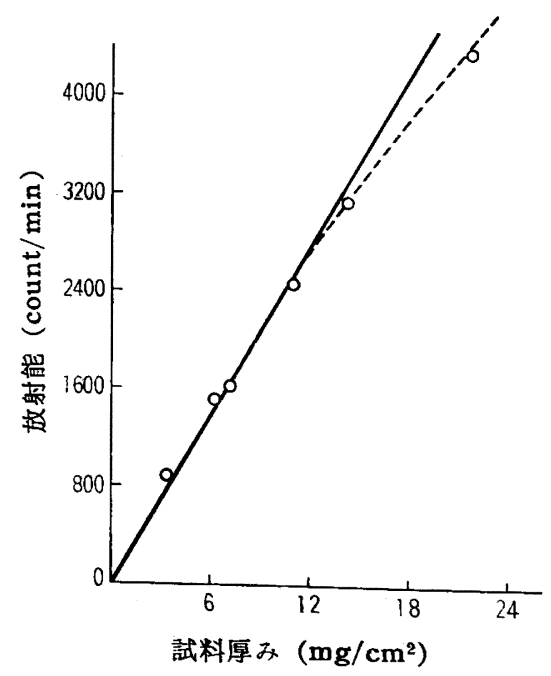

図 $4 \mathrm{Sb}$ の自己吸収曲線 
放射能強度は直線的に増大するはずである。

この結果によるとヒ素およびアンチモンの $\beta$ - エネルギーは 比較的大きいため, いずれる $12 \mathrm{mg} / \mathrm{cm}^{2}$ までは補正を必要とし ないことがわかる。本実験では, 試料厚みが $10 \mathrm{mg} / \mathrm{cm}^{2}$ 以下で あったから補正は行なわなかった。

\section{8 空実験}

標準溶液中には加えた目的元素の一定量のほかに，偽イン鉄あ るいは偽イン石溶液をつくるのにもちいた陚薬からの目的元絜の 污染が考えられるが，これは空実験を行なって補正した。

\section{9 分析感度}

放射化分析の感度は, 計測しうる程度の放射能を与えるのに必 要な目的元素の重量をむってあらわされる。

中性子流束 $3 \times 10^{11} \mathrm{n} / \mathrm{cm}^{2} / \mathrm{sec}$, 毎日 5 洔間 3 日の断続照射を 行ない, 照射終了時から分析操作終了時までに 48 時間, 化学操 作の収率 $50 \% ， \beta$ 線計数效率 $10 \%$ と仮定して，50 cpm 得る のに必要な七素およびアンチモンの重量はそれぞれおよそ 0.04 $\mu \mathrm{g}$ と $0.025 \mu \mathrm{g}$ となる。実験の結果は,この値とよい一致を示 した。

\section{3 分析結果と考察}

\section{1 分析試料}

分析に供したイン石はつぎの 6 個である16)。

1) Henbury: 中央オーストラリアの McDonnell Range で 1931年に発見されたイン鉄で medium octahedrite に属する。

2) Canyon Diablo: 米国アリゾナ州の Coconino County で 1891 年に発見されたイン鉄で coarse octahedriteに属する。

ともに広く知られた代表的なイン鉄である。

3) Forest City： 米国アイオワ州の Winnebago County に 1890 年 5 月 2 日落下したイン石でコンドライト (brecciated spherical bronzite-chondrite) に属する。Urey, Craig の分 類によれば, High iron group に属し金属相部分は $21.06 \%$ で ある17)。

4) Modoc: 米国カンサス州の Scott County に 1905 年 9 月 2 日落下したイン石でコンドライト (veined white hypers. thene-chondrite) に属する。Low iron group に属し金属相部 分は $7.27 \%$ である。

5) Nuevo Laredo: 詳細不明の石質イン石でエイコンドライ ト (achondrite) とされているがコンドライトとする研究者むあ

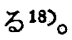

6) Admire: 米国カンサス州 Lyon County で 1881 年に発 見された石鉄イン石でパラサイト(brecciated pallasite) に属す る。

$$
\text { この試料はかなり風化を受けている。 }
$$

\section{2 結 果}

イン石中のヒ素, アンチモンの定量結果を表 4 に示す。

Henbury のヒ素の 4 回の実験值のうち*印の 22.3 はただ一 つとびはなれた值で，なんらか不明の原因による異常結果と考え て平均から除いた。同様に Nuevo Laredoのアンチモンの*印 も除いた。コンドライトの值は，よく行なわれているようなケイ

16) G. T. Prior, M. H. Hey, "Catalogue of Meteorites" (1953) William Clowers and Sons, Ltd., London.

17) H. C. Urey, H. Craig, Geochim. et Cosmochim. Acta 4, 36(1953)

18) C. Patterson, Geochim. et Cosmochim. Acta 7, 151 (1955).

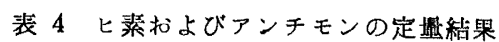
分析試 料

1 ン 鉄: 1. Henbury

$\mathrm{As}(\mathrm{ppm}) \quad \mathrm{Sb}(\mathrm{ppm})$

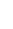

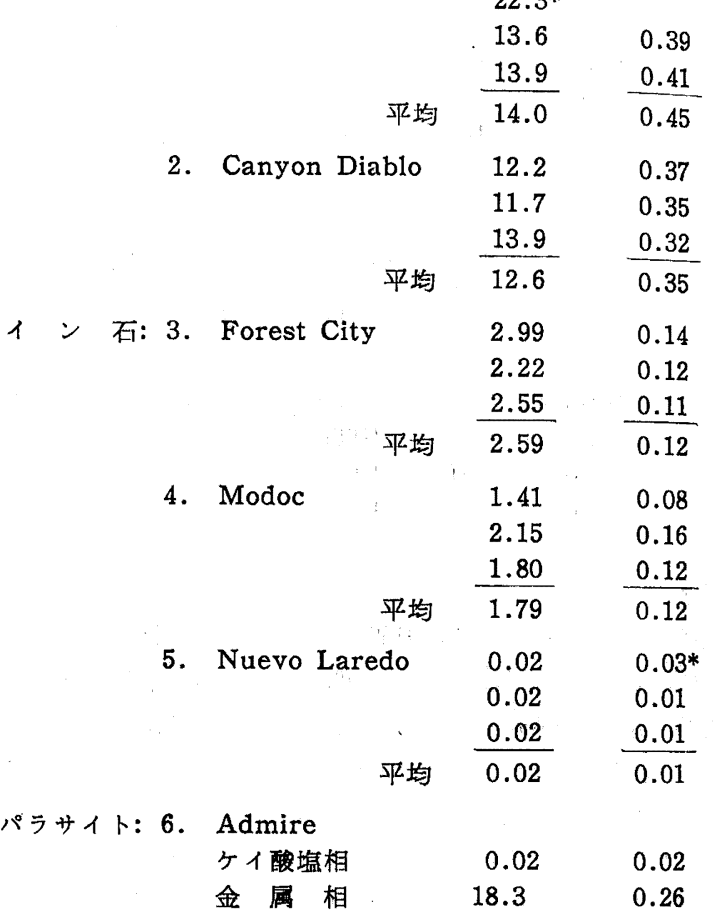

酸塭相，金属相，硫化物相などの分離は行なわず，粉末試料全体 を処理して得られた值である。

\section{3 考 察}

表 4 の結果から得られる各イン石の七素およびアンチモンの存 在量と，ヒ素対アンチモンの比を表 5 に示す。

\begin{tabular}{|c|c|c|c|}
\hline 1ン 石 & As (ppm) & $\mathrm{Sb}(\mathrm{ppm})$ & $\mathrm{As} / \mathrm{Sb}$ \\
\hline \multicolumn{4}{|l|}{12 鉄 } \\
\hline Henbury & 14.0 & 0.45 & 31 \\
\hline Canyon Diablo & 12.6 & 0.35 & 36 \\
\hline \multicolumn{4}{|l|}{ コンドライト } \\
\hline Forest City & 2.59 & 0.12 & 22 \\
\hline Modoc & 1.79 & 0.12 & 15 \\
\hline \multicolumn{4}{|l|}{ エイコンドライト } \\
\hline Nuevo Laredo & 0.02 & 0.01 & 2 \\
\hline \multicolumn{4}{|l|}{ パラサイト } \\
\hline ケイ酸塩相 & 0.02 & 0.02 & 1 \\
\hline 金 属 相 & 18.3 & 0.26 & 70 \\
\hline
\end{tabular}

イン石中のヒ秦およびアンチモンの值についての従来の報告を 要約して表 6,7 亿示す。

Noddack らの值はあきらかに高すぎるようである。大西らは， Henbury と Canyon Diablo の七素についてそれぞれ 3.6, $8.1 \mathrm{ppm}$ という值を得ているが，著者らの得た值はこれにくらべ 前者は 4 倍, 後者では大差はない。アンチモンについてはそれぞ れ $0.5,0.8 \mathrm{ppm} て ゙ ，$ 著者らの值と大差はない。

また, Smales らはイン石中のヒ素, アンチモンの放射化分析 を著者らとほとんど同時に独立に行なっており，その結果による とヒ素は Henbury $10.5 \mathrm{ppm}$, Canyon Diablo $8.3 \mathrm{ppm}$ で蓄 


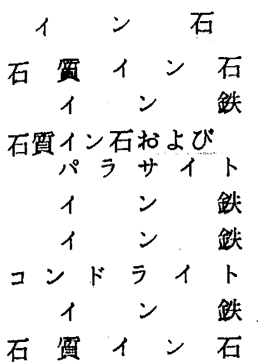

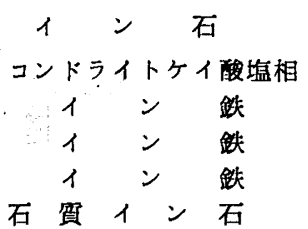

武料数
3
3
5
1
2
11
15
2

\begin{tabular}{c}
\multicolumn{2}{c}{ 表 } \\
試料数 \\
42 \\
16 \\
2 \\
15 \\
2
\end{tabular}

表 6 イン石中の七素

\begin{tabular}{|c|c|c|}
\hline 方 & 法 & 献 \\
\hline 発 & 光”分 光 & $\begin{array}{l}\text { Noddack }{ }^{19)}(1931) \\
\text { " }\end{array}$ \\
\hline & " & Johnnson, et al.20) (1943) \\
\hline & " & " \\
\hline 比 & " & $\begin{array}{l}\text { Onishi, Sandell7) (1955) } \\
\text { " }\end{array}$ \\
\hline & $\begin{array}{l}\text { 子放射 化 } \\
\text { " }\end{array}$ & $\begin{array}{l}\text { Smales, et al. }{ }^{21)} \text { (1958) } \\
\text { " }\end{array}$ \\
\hline
\end{tabular}

$5 \sim 30$, 平均 15

$40 \sim 300$, 平均 160

$10 \sim 100$

$$
<100
$$

$8.1,3.6$

双均 2.2

$0.6 \sim 30$

30,33
ンチ. モ ン

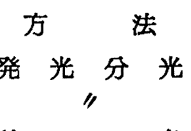

比色

中性子放射 化

$\mathrm{Sb}(\mathrm{ppm})$
平均 0.1
平均 2.0
$0.8,0.5$
$0.01 \sim 0.78$
$0.22,0.23$

$\mathrm{Sb}(\mathrm{ppm})$

発光”分光
比
中性子放射化
"

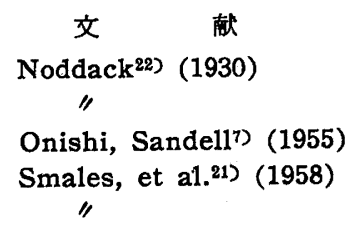

者らの方がやや商いがほぼ一致している。アンチモンについては Henbury $0.43 \mathrm{ppm}$, Canyon Diablo $0.31 \mathrm{ppm}$ であって, こ れは著者らの $0.45 \mathrm{ppm}, 0.34 \mathrm{ppm}$ ときわめてよい一致を示し ている。

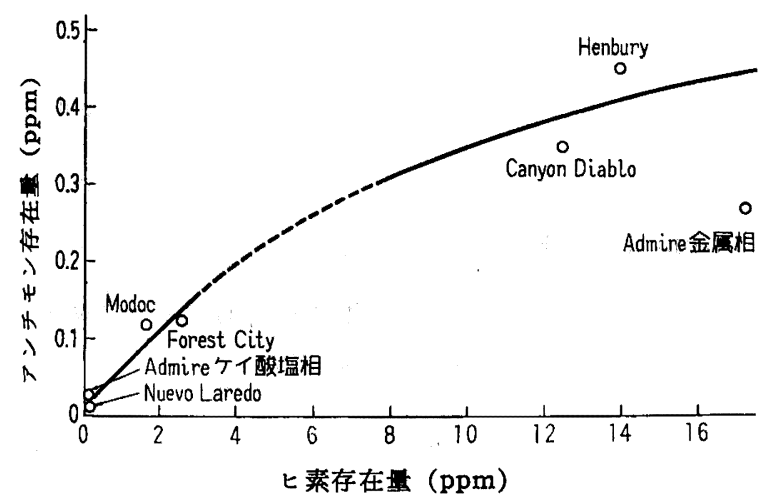

四 5 イン石物質中のヒ秦とアンチモンの存在量の関係

19) I. Noddack, W. Noddack, Z. physik. Chem. A 154, 207 (1931). 20) W. W. A. Johnson, D. P. Norman, Astrophys. J., 97, 46(1943).
さて，ヒ素とアンチモンとの相関をみると図 5 のようになり， 两者の間には正の相関があることが認められる。

ヒ素とアンチモンのケイ酸塩相と金属相への分配は，あきらか に両元素とも 金属相に濃縮しているが，その度合は異なってい る。各イン石におけるヒ素対アンチモンの比を表 5 の最後欄に示 した。パラサイトのケイ酸塩相，および主としてヶイ酸塩からな る Nuevo Laredoにおける七素対アンチモンの值は低く（1〜 2), コジドラィトでは増大し (15〜20), イン鉄およびパラサイ トの金属相ではさらに增大している(30〜70)。このことから，ヒ 素とアンチモンはともに 親鉄的であるといえるが，七素の方が アンチモンよりも親鉄性がさらに強いことを示するのと考えら れる。

本研究の费用の一部は交部省科学研究費(JRR-1 共同利用総合 研究）によった。とてに記して感謝する。

(1958 年 11 月, 第 2 回放射化学討論会(一部)講演)

20) A. A. Smales, et al., 2nd UN International Conference on Peaceful Uses of Atomic Energy, 2, 242 (1958).

22) I. Noddack, W. Noddack, Naturwissenschaften 18, 757 (1930).

\section{中性子放射化によるイン石中の白金, イリジゥム, パラジゥムの定是*1}

(昭和 35 年 10 月 18 日受理)

$$
\text { 浜口博十.中井敏 夫什・龟本雄一郎什 }
$$

白金,イリシウム，パラシウムの放射化学的精製法を検討し，重量分析的な方法，イオン交換樹脂法，溶媒抽出法を組み合わせ るととにより十分满足のいく精製法が得られた。との精製法を用いて放射化分析法を確立した。

陚料と，武料に組成のよく似た“ mock”に既知量の白金，イリシウム，パラシウムを加えた標準陚料と觉それぞれ石英管に封 じならべてカプセルに入れたものを JRR-1 中で 3 日間中性子照射を行なった。照射した試料和よび標準試料から担体の存在の 下で上述の精製法にしたがって純料な白金，イリシウム，パラシウムをとり出し GM 計数管で測定した放射能の強さを比較して， てれら 3 元素を定题した。分析した試料はイン鉄 3 種, 石留イン石 3 種, パラサイト1種（金属相打よびケイ酸壏相）である。 